\author{
T.P. Pritvorova ${ }^{1}$, S.G. Simonov ${ }^{2}$, A.K. Atabayeva ${ }^{3, *}$ \\ ${ }^{1,3}$ Karagandy University of the name of academician E. A. Buketov, Kazakhstan \\ ${ }^{2}$ Tyumen Industrial University, Russian Federation \\ 1'pritvorova_@mail.ru, ${ }^{2}$.simonova.67@mail.ru, ${ }^{3}$ atabaeva@list.ru \\ ${ }^{1}$ http://orcid.org/0000-0002-6306-3960, ${ }^{2}$ https://orcid.org/0000-0002-7231-2914, \\ ${ }^{3}$ https://orcid.org/0000-0002-4644-1843 \\ ${ }^{1}$ Scopus Author ID: 55816012800, ${ }^{2}$ Scopus Author ID: 56166169400 \\ ${ }^{1}$ Researcher ID: U-7564-2018
}

\title{
Temporary and part-time employment in the European labor market: factors, trends, features
}

\begin{abstract}
Object: The object of this article is to investigate factors of temporary and part-time employment emergence in Europe to determine country characteristics and trends in their development in the post-industrial economy conditions.

Methods: For the purpose of the research we have used methods of statistical grouping, analysis of dynamics, structure and variation. Statistical analysis of the variation in temporary and part-time employment in European countries is based on the coefficient of variation. We have also used data from Eurostat and the European Social Survey (ESS).

Results: We have identified features and both objective and subjective factors contributing to the emergence of non-standard employment forms. We have evaluated homogeneity of the population of European countries on studied non-standard employment types: both temporary and incomplete. Based on the results obtained, the prevalence of temporary and part-time employment in Europe was determined. Based on the rating of countries by the share of non-standard types of employment in the total employment of the population, we have identified leaders and outsiders of the said rating.

Conclusions: Statistical analysis has shown growth in both temporary and part-time employment; this reflects one of the trends in the evolution of labor markets in European countries. High coefficient of variation values indicate heterogeneity of European countries in the share of temporary and part-time employment. Indeed, a number of countries enjoy a significant increase and a large coverage scale. And yet there are countries where the applicability of fixed-term and incomplete contracts is quite low, and even if it sees an increase, it is a very slight one. The main reasons for heterogeneity depend on the current economic situation and the level of production development in a particular country. They also lie in differences in the applicable legal acts and measures to protect the employee rights.
\end{abstract}

Keywords: temporary employment, part-time employment, factors, trends, the heterogeneity of countries, the European labor market.

\section{Introduction}

Influenced by many factors that caused changes in the supply and demand for labor, a standard employment, customary for industrial economies of the XX century, began to fade into the background, giving way to less stable forms of social and labor relations consolidation. In contrast to stable employment under an indefinite employment contract and full-time employment, such forms as part-time and secondary employment, temporary employment, self-employment, etc. are a growing trend (Shelomentseva, Bespalyy, Beisembayeva, Soltangazinov, 2019). Despite the increased attention of the scientific community to this topic, there is no common point of view on the impact of non-standard employment on economic development and quality of working life of the working population. In this regard, there is a pressing need to study various factors affecting development of non-standard employment forms to identify their features (Taubayev, Legostayeva, Serikova, Orynbassarova, (2019).

\footnotetext{
* Corresponding author.

E-mail address: atabaeva@list.ru
} 
The evolution of the labor market in European countries primarily reflects in the spread of non-standard employment forms. Contracts for temporary and part-time work enjoy the largest share in the structure of non-standard employment forms. Formation of this phenomenon is influenced by a combination of factors, some of which are common for all countries, the others are individual.

The author performs a statistical analysis of temporary and part-time employment indicators using Eurostat information base and reveals the heterogeneity of countries in the spread of this phenomenon. The novelty of the research does not consist only in identification of the features of temporary and part-time employment in different countries, but also in assessment of the role of public policy in shaping trends of its development.

\section{Literature Review}

Non-standard forms of employment have become a modern feature of labor markets around the world and thus, are in the center of many scientists' attention. One of the first authors to study "non-standard employment" and basic reasons for its appearance in the post-industrial economy are Kalleberg, A. (Kalleberg, 2000), Gimpelson, V. and Kapelyushnikov, R. (Gimpel'son, Kapelyushnikov, 2006) and others.

Researchers Bak-Grabowska, D., Jagoda, A. (2016) believe that flexible employment forms characterize the growing diversity of opportunities to better utilize people's abilities, their human potential, and overcome the limitations of standard employment.

Socio-economic risks caused by the growth of flexible employment forms and the replacement of stable labor relations with unstable ones that restrict and infringe on the labor and social rights of employees are reflected in the works by (Avlijas, 2019) (Schoukens, Barrio, Montebovi, 2018).

Salladarre, F., \& Hlaimi, S. (2014). Monusova, G.A. (2018) reveal and analyze ways of spreading nonstandard employment in European countries.

Bobkov, V.N. (2018), Orynbassarova, Y., Serikova, G., Pritvorova, T., Legostayeva, A., Kuttybayeva, N., Komekbayeva, L. (2019) conduct a comparative assessment of non-standard employment forms in the OECD and CIS countries.

\section{Methods}

We have used the following statistical methods: grouping based on ranking and the method of absolute differences, calculating absolute and relative deviations, calculating the coefficient of variation.

We have calculated the coefficient of variation in the following sequence:

1) Calculation of the range of variation. The absolute index of variation shall be calculated by the formula 1

$\mathrm{x}_{\max }$ is the largest value of the options;

$$
\mathrm{R}=\mathrm{x}_{\max }-\mathrm{x}_{\min }
$$

$\mathrm{x}_{\min }$ is the lowest value of options.

2) The mean square deviation is the square root of the variance

$$
\sigma=\sqrt{\frac{\sum\left(x_{i}-\bar{x}\right)^{2} f_{i}}{\sum f_{i}}},
$$

$\left(x_{i}-\bar{x}\right)^{2}$ is the square of deviations of each attribute value from the arithmetic mean;

$f_{i}$ is the frequency for each attribute.

3) Coefficient of variation is the most common fluctuation indicator used to assess the typicity of the average (formula 3).

$$
V_{\sigma}=\frac{\sigma}{\bar{x}} \times 100 \%
$$

$\sigma$ is the average square deviation;

$\bar{x}$ is the average value of the attribute.

The greater the spread of attribute values around the average, the greater the coefficient of variation and the less representative the average is. As a rule, it is assumed that if $V_{\sigma}>33 \%$, this indicates a large fluctuation of the attribute in the aggregate, and the aggregate is heterogeneous. 
Results

In the era of industrialization, standard employment has been the main employment form. This was due to the accelerated growth of industrial production and conveyor technologies, which required the organization of labor in this particular form.

Standard employment would base on an employment contract with the following distinctive features:

- long-term employment relationships that could not be terminated by the employer without significant compensation being paid to the employee;

- full-time employment with one employer;

- performance of work duties directly on the site and under the employer supervision (Monusova, 2018).

A deviation on any of the parameters is identified as non-standard employment.

Standard labor relations would prevail in the industrial world that would dominate for most of the twentieth century. (Gimpel'son, Kapelyushnikov, 2006).

By the 70s of the XX century, the set of conditions under which standard employment could dominate began to transform, and the movement towards a more flexible post-industrial economy has taken over.

A number of objective and subjective factors have contributed to the development of non-standard employment (Figure 1).

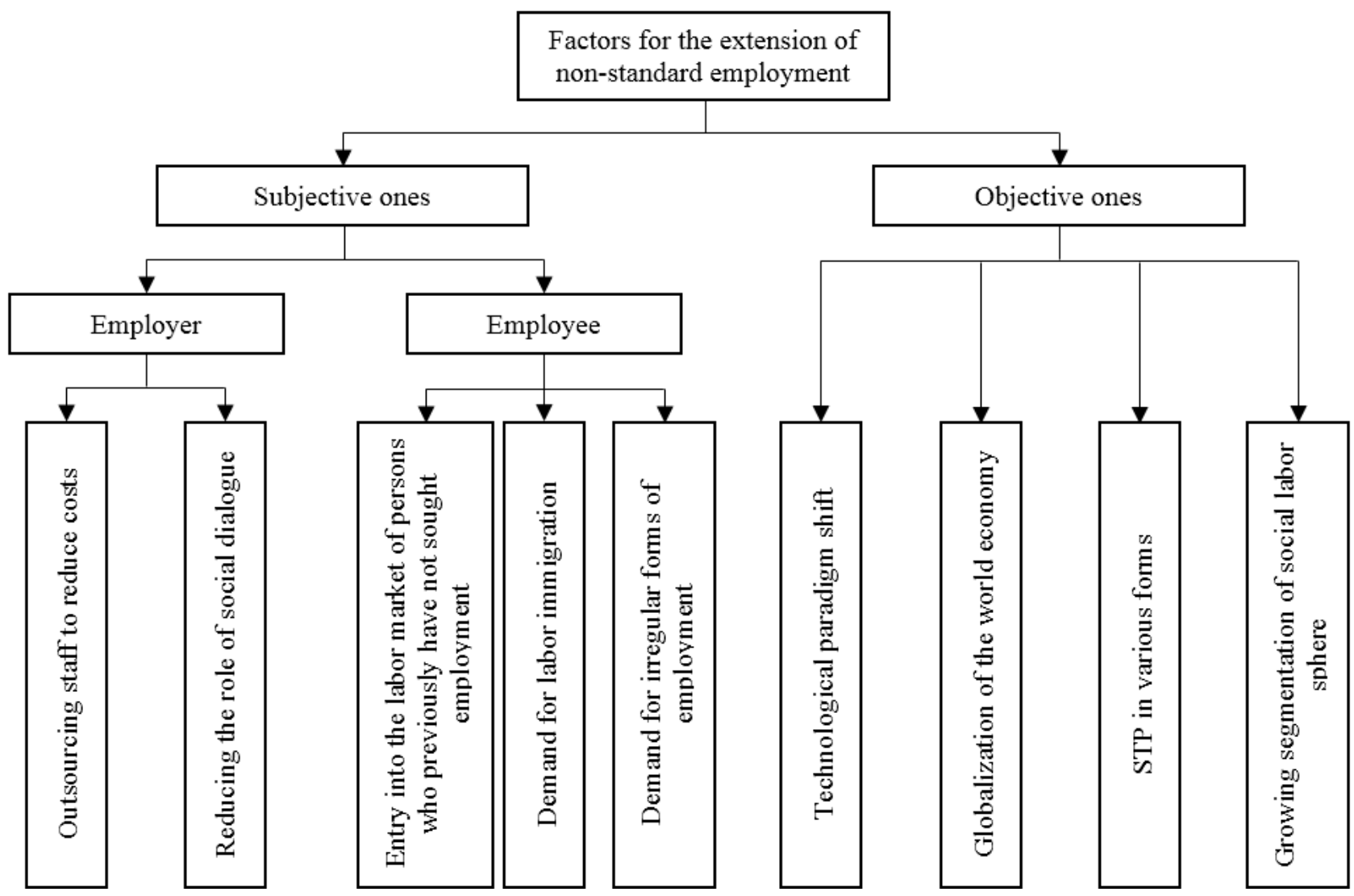

Figure 1. Factors contributing to non-standard employment emergence

Note: Compiled by the authors

In the context of a techno-economic paradigm shift and globalization of value chains, there was a parallel change in the structure and content of labor processes. As a result, a demand for non-standard employment arose from employers who wanted to reduce their costs both directly (by transferring employees to non-standard employment schedules) and using outsourcing contracts. The impact of these two factors on the labor market causes changes in the characteristics of labor supply and demand (Zenkova, 2017).

New level technology paradigms have freed up some workers while the movement of industrial production to developing countries has played a role in reducing standard employment. Information and communication technologies have contributed to the dilution of employment standards, and flexible em- 
ployment schedules in services have been a response to differentiated consumer demand in countries with rising standards of living and consumption. Service sector has begun to impose new requirements on employees, such as mobility of skills, ability to work flexibly, ability to make quick decisions and work in irregular situations.

The use of computer technologies and scientific and technical progress have become a factor in the creation of highly specialized companies that offer their services to perform certain production functions on the terms of outsourcing. Development of such entities has led to a demand for mobile workers who perform specialized jobs in non-standard employment (Musayev, 2017).

Also, the growth of non-standard employment was greatly influenced by demographic shifts in the structure of the labor force, which manifested in the mass entry of housewives into the labor market. The supply of work for non-standard jobs has increased with the involvement of pensioners and students who preferred to work on a flexible schedule and reduced working hours. At the same time, the employment of this category of workers did not require legal labor guarantees. Increased migration flows in the global economy have also increased the supply of labor "on any terms."

\section{Temporary employment in European countries}

One of the first forms of non-standard employment was work under labor contracts with a specific limited validity period. This type of employment is becoming more widespread. In 2002, the share of European Union temporary workers was $11.2 \%$ of total employment, and in 2018 it went up to $13.2 \%$ (Table 1). In other words, the dynamics of a small increase in the share of temporarily employed workers has been observed over the past 16 years.

A number of economic reforms in Europe have been linked, among other things, to increasing the flexibility of the labor market by making it easier for employers to use temporary employment contracts (Imdorf, Helbling, Inui, 2017). Fixed-term contracts have been introduced into the legal framework as a result of legislative changes in Spain, Italy, Germany and several other countries in the 1980s and during the 2000s. The main objective of such measures is to counter the negative effects on employment associated with slowing economic growth and increased labor market tensions. At first, temporary employment was only allowed for young workers entering the labor market, but gradually it extended to other worker categories, as it was in Portugal and Spain. These reforms would preserve the protection of "permanent" jobs and would at the same time encourage firms to extensively use workers with fixed-term contracts, leading to ambivalence in most European labor markets. In France, the increase in temporary employment can be explained by the accumulation of temporary workers: each year between 1993 and 2011, more and more unemployed people would agree to short-term work.

The economic crisis in Europe had a number of different consequences for the share of temporary contracts in different countries:

1) Due to instability and uncertainty, some companies have started to hire workers on very short temporary contracts to replace permanent employees. This practice could be observed in France, Italy and Ireland, where temporary employment increased between 2009 and 2014. For example, in Ireland, between 2006 and 2012 , the share of fixed-term contracts among new employees increased from $26.7 \%$ to $48.4 \%$. It also increased from $22.1 \%$ to $75 \%$ in the United Kingdom and reached more than $75 \%$ in $2011-2012$ in Poland, Portugal, Slovenia, and Spain.

2) Reduction of the labor force was inevitable, and it would often occur at the expense of workers in the periphery without renewing temporary contracts. This strategy was observed in Spain, where temporary employment declined from $28.3 \%$ in 2008 to $22.9 \%$ in 2013 .

Important differences could be observed in different occupations: even though temporary employment declined for high and medium skilled workers, it continued to grow for the lowest skilled workers. As a result, a risk of forming "dissatisfaction" in the employee would arise, which could later cause his professional burnout (Pritvorova, Tasbulatova, 2020).

Table 1 shows that there is a significant differentiation between countries in the growth of temporary employment. Among the European Union countries, temporary employment is most widespread in Portugal, Poland and Spain, where more than $20 \%$ of all workers can be classified as temporary. Spain was recognized as an undisputed leader, as it was back in 2002 , where $26.4 \%$ of all employees signed temporary contracts. But in 2002, this figure was $31.1 \%$, which is $4.7 \%$ higher than in 2018. Poland came in 2nd place, where the share of fixed-term contracts increased from $14.8 \%$ in 2002 to $23.9 \%$ in 2018 . 
Table 1. Percentage of employees with fixed-term employment contracts among all employed in 2002 and 2018 (\%)

\begin{tabular}{|c|c|c|c|c|c|c|}
\hline Countries & 2002 & 2018 & $\begin{array}{l}\text { Absolute } \\
\text { Growth }\end{array}$ & $\begin{array}{c}\text { Growth for } \\
2002-2018(\%)\end{array}$ & $\begin{array}{c}\text { Absolute difference between } \\
\text { neighboring positions in } \\
\text { column } 3 \text { (p.p.) }\end{array}$ & $\begin{array}{l}\text { Grouping of countries } \\
\text { by the share of tempo- } \\
\text { rary workers in total } \\
\text { employment }(\%)\end{array}$ \\
\hline 1 & 2 & 3 & 4 & 5 & 6 & 7 \\
\hline Spain & 31,1 & 26,4 & $-4,7$ & $-15,1$ & & \multirow{4}{*}{ Group 1} \\
\hline Poland & 14,8 & 23,9 & 9,1 & 61,5 & 2,5 & \\
\hline Portugal & 20,6 & 21,5 & 0,9 & 4,4 & 2,4 & \\
\hline Croatia & 9,4 & 19,3 & 9,9 & 105,3 & 2,2 & \\
\hline The Netherlands & 11,7 & 17,6 & 5,9 & 50,4 & 1,7 & \multirow{6}{*}{ Group 2} \\
\hline Italy & 9,5 & 16,8 & 7,3 & 76,8 & 0,8 & \\
\hline France & 13,0 & 15,5 & 2,5 & 19,2 & 1,3 & \\
\hline Finland & 15,5 & 14,9 & $-0,6$ & $-3,9$ & 0,6 & \\
\hline Slovenia & 13,9 & 14,8 & 0,9 & 6,5 & 0,1 & \\
\hline Sweden & 13,4 & 13,8 & 0,4 & 3,0 & 1,0 & \\
\hline Cyprus & 9,2 & 13,7 & 4,5 & 48,9 & 0,1 & \\
\hline European Union & 11,2 & 13,2 & 2,0 & 17,9 & 0,5 & \\
\hline Greece & 11,4 & 11,2 & $-0,2$ & $-1,8$ & 2,5 & \multirow{14}{*}{ Group 3} \\
\hline Germany & 9,3 & 10,8 & 1,5 & 16,1 & 0,4 & \\
\hline Belgium & 7,0 & 9,8 & 2,8 & 40,0 & 1,0 & \\
\hline Luxembourg & 3,7 & 9,3 & 5,6 & 151,4 & 0,5 & \\
\hline Switzerland & 7,6 & 9,1 & 1,5 & 19,7 & 0,2 & \\
\hline Denmark & 7,9 & 8,8 & 0,9 & 11,4 & 0,3 & \\
\hline Ireland & 3,9 & 8,6 & 4,7 & 120,5 & 0,2 & \\
\hline Czech & 7,2 & 8,2 & 1,0 & 13,9 & 0,4 & \\
\hline \begin{tabular}{|l} 
Iceland \\
\end{tabular} & 5,1 & 8,1 & 3,0 & 58,8 & 0,1 & \\
\hline \begin{tabular}{|l|} 
Slovakia \\
\end{tabular} & 4,5 & 7,8 & 3,3 & 73,3 & 0,3 & \\
\hline Norway & 9,1 & 7,4 & $-1,7$ & $-18,7$ & 0,4 & \\
\hline Malta & 3,2 & 7,4 & 4,2 & 131,3 & 0,0 & \\
\hline Hungary & 7,2 & 7,1 & $-0,1$ & $-1,4$ & 0,3 & \\
\hline Austria & 3,8 & 6,8 & 3,0 & 78,9 & 0,3 & \\
\hline Great Britain & 5,5 & 4,9 & $-0,6$ & $-10,9$ & 1,9 & \multirow{6}{*}{ Group 4} \\
\hline Bulgaria & 5,9 & 3,9 & $-2,0$ & $-33,9$ & 1,0 & \\
\hline Estonia & 2,2 & 3,0 & 0,8 & 36,4 & 0,9 & \\
\hline Latvia & 10,8 & 2,6 & $-8,2$ & $-75,9$ & 0,4 & \\
\hline Lithuania & 7,4 & 1,4 & $-6,0$ & $-81,1$ & 1,2 & \\
\hline Romania & 0,9 & 1,1 & 0,2 & 22,2 & 0,3 & \\
\hline
\end{tabular}

In the Netherlands, the share of temporary labor increased in 2018 compared to 2002 from $11.7 \%$ to $17.6 \%$, and in Italy from $9.5 \%$ to $16.8 \%$. In Croatia, the share of fixed-term contracts rose by about 10 p.p. over the same period and by 2018 was $19.3 \%$. However, some countries saw the loss of temporary employment popularity. A significant decrease is observed in the Baltic countries, such as Latvia and Lithuania, with the share of fixed-term contracts more than halved in 2018 compared to 2002.

The lowest values of $0.9 \%$ in 2002 and $1.1 \%$ in 2018 were recorded in Romania. Countries such as Ireland, Croatia, Italy, Luxembourg, Malta, Austria, and Slovakia saw the increase in the share of temporary employment in 2018 by almost two times compared to 2002. The share of fixed-term contracts looks robust enough in the following countries: Greece (11.4-11.2\%), Hungary (7.2-7.1\%), Romania (0.9-1.1\%), Finland (15.5-14.9\%), Sweden (13.4-13.8\%), and Great Britain (5.5-4.9\%).

We have calculated the coefficient of variation for both 2002 and 2018 based on Eurostat data and the percentage of temporary employment in European countries (Table 2). First, we shall group the studied population, in this case, the countries of the European Union, by the share of temporarily employed in the total employment for 2018. Ranking and determining the absolute difference between countries has allowed us to distinguish 4 groups of countries (Table 1). 
As the grouping shows, countries differ not only in the trends of fixed-term contracts growth, but also in the extent of their coverage (Table 1). According to this criterion, we can distinguish the third group, which has the maximum coverage of 14 countries while the share of temporary employment is from 6 to $12 \%$.

Table 2. Variation values for 2002 and $2018(\%)$

\begin{tabular}{|l|c|c|c|}
\hline \multicolumn{1}{|c|}{ Indicators } & 2002 & 2018 & Absolute variation \\
\hline Variation range & 30,2 & 25,3 & $-4,9$ \\
\hline Mean value & 9,28 & 10,9 & $+1,62$ \\
\hline Standard deviation & 5,9 & 6,24 & $+0,34$ \\
\hline Coefficient of variation & 63,58 & 57,24 & $-6,34$ \\
\hline Note-Compiled by the authors based on Table 1 & \\
\hline
\end{tabular}

The range of variation was $30.2 \%$ and $25.3 \%$. This indicates a fairly high amplitude of the temporary employment share in European countries in both 2002 and 2018. However, a 4.9 p.p. decrease in this indicator in 2018 indicates a narrowing of the gap between the extremes.

The calculated coefficient of variation has fairly high values of 63.58 and $57.24 \%$ significantly exceeding the threshold of $33 \%$, which indicates that the growth of temporary employment in European countries is heterogeneous. The variation of the indicator reflects the variability of the studied phenomena. Therefore, a decrease in the coefficient of variation by 6.34 p.p. in 2018 shows a decrease in the process variability or a moderate stabilization of the temporary employment growth. This fact also confirms a decrease in the variation range and an increase in the mean value by 1.62 p.p.

Large fluctuations in individual values of the share of fixed-term contract employees in European countries indicate the heterogeneity of the population, and both atypical and unreliable mean value, that is, it does not give an accurate description of the population in question. The calculated mean values were $9.28 \%$ (2002) and 10.9\% (2018). In 2002, 3 countries (9\%) maintained the average level, 13 countries (41\%) exceeded it, and 16 countries (50\%) were below the average level. In 2018, only one country maintained the average level of temporary employment, 13 countries (41\%) exceeded it and 18 countries $(56 \%)$ had a lower value. In other words, the disparity of values is very high.

The main reasons for heterogeneity depend on the current economic situation in a particular country, as well as on differences in the applicable legal acts and measures to protect employee rights. For example, labor markets in the Netherlands, Sweden and Germany are strictly governed by law and have a certain procedure for protecting employee rights (ILO, 2016).

Taking into account that the lower the coefficient of variation, the more stable the system, we can conclude that in our research, the decrease in the coefficient of variation in 2018 shows small shifts towards homogeneity and stability of the temporary employment growth in Europe.

Over the past 30 years, in many European countries, the proportion of women in employment has increased significantly. If in Spain it was equal to $26.2 \%$ in 1986, by 2018 it had risen to 55\%. In Belgium, this percentage increased over the same period from $37.6 \%$ to $57.2 \%$, in France from $49.4 \%$ to $61.4 \%$, in Germany from $48.5 \%$ to $70.8 \%$, and in the Netherlands from $36 \%$ to $70 \%$ (OECD, 2020). Many of women who entered the labor market are interested in non-standard forms of employment. The flow of migrants to European countries applying for any jobs is also noticeably increasing. If in 1990 immigrants made up $6.8 \%$ of the total European population, by 2017 it went up to $10.5 \%$.

A comparison of temporary employment between men and women shows that the gender gap was not as large in 2018 at the EU level: $12.6 \%$ for men and 13.8\% for women (Eurostat, 2020).

Let us consider the growth factors of fixed-term contracts in Spain, which have been maintaining leadership for many years, second only to Poland in the post-crisis period.

Spain has one of the highest rates of temporary employment not only in Europe, but worldwide as well. Temporary work arose in 1984 during a period of weak economic growth. To promote employment, the state has introduced small legal amendments that allowed the use of temporary contracts for any type of work, including permanent ones. As a result, temporary employment increased sharply, reaching $35 \%$ and spreading to sectors that were not subject to seasonal fluctuations. In 1994, the first reform was implemented to combat this growth, but by then businesses had become accustomed to using temporary contracts in their operations, and many of them have made significant adjustments to their work cycles. In the following years, the use of temporary contracts would increase as production processes constantly adapted to the coexistence of temporary and permanent contracts. As a result, temporary contracts reinforced existing job segmentation by promoting the division of employees into "bad work - temporary contract" or "good work - permanent 
contract." Despite state attempts to reduce the number of employees on temporary contracts by offering businesses financial assistance to convert temporary contracts into permanent ones, in 2008 about a third of employees still worked on temporary contracts.

Another factor contributing to the use of temporary contracts in Spain was the difference in the regulation of fixed-term and indefinite contracts (the difference in the cost of layoffs). Changes to the regulation of indefinite contracts were part of the 1994 reform, as well as both 2010 and 2012 reforms. The 2012 reform affected the cost of layoffs on indefinite contracts (downwards). However, this reform could not change the attitude to the reorganization of jobs at the company level. According to Eurostat statistics, the number of temporary employees increased by 14.7\% in December 2013 and January 2014.

Among Eastern European countries, Poland is a prime example of ever-growing temporary employment. From 2009 to 2016, it surpassed Spain in the use of temporary work, taking the leading position for this period. This may be due to the fact that Poland is the largest agricultural employer in the EU and employment in this area is seasonal (Avlijas, 2019).

Thus, the frequency of temporary employment during the period under review has shown an upward trend in most countries. A feature of the expansion of temporary contracts in Spain is the easing of employers' obligations to employees during the crisis, which turned out to be beneficial to many of them and remained the norm in future practice. An additional factor was the agricultural specialization of the Spanish economy, as well as the economies of Poland and Portugal, which encourages mass seasonal employment, including migrant workers. The steady trend in these countries is to maintain and somewhat expand the practice of temporary employment, which is determined by both easing of legal regulations and specialization of economies.

In some countries where temporary employment is low, there are minimal restrictions to protect permanent employees from individual termination in accordance with employment protection legislation. These are such countries as the Great Britain, Hungary, Ireland, Estonia and Slovakia.

It is a common practice in all European countries to use fixed-term contracts to replace employees who are absent due to maternity leave, nursing, education or other reasons. In a number of countries, businesses also use temporary employment contracts when hiring employees on probation. This allows for checking professional qualifications of potential employees, their abilities and social competencies before accepting them on a permanent basis.

\section{Part-time employment}

A significant proportion of non-standard employment is part-time employment.

According to the 1994 ILO Part-Time Work Convention No. 175, the term "part-time employee" is defined as an employee whose working hours are less than those of full-time employees. This definition does not contain any indication of the actual number of working hours below which workers are considered to work part-time. National legislation in different countries has adopted different approaches to this issue. Most European countries, in particular the Baltic States and Eastern and Southern Europe, adhere to the definition of part-time work similar to the definition in a Convention No. 175, that is, working hours less than the legal limit (less than 30-35 hours per week). Some countries set a minimum number of working hours for part-time employment in their legislation. For example, Denmark has set a minimum of 15 hours a week, France a minimum of 24 hours a week. It is also necessary to consider the fact that the number of hours of work may sometimes depend on the relevant profession or activity.

Part-time work significantly exceeds temporary employment as a proportion of total employment in many countries (Table 3 ).

Table 3. Percentage of part-time workers in total employment in European countries for 2002-2018 (\%)

\begin{tabular}{|l|c|c|c|c|c|c|}
\hline \multicolumn{1}{|c|}{ Countries } & 2002 & 2018 & $\begin{array}{c}\text { Absolute } \\
\text { growth }\end{array}$ & $\begin{array}{c}\text { Growth for } \\
2002-2018 \\
(\%)\end{array}$ & $\begin{array}{c}\text { Absolute difference } \\
\text { between neighboring } \\
\text { positions in column 3 } \\
\text { (p.p.) }\end{array}$ & $\begin{array}{c}\text { Grouping of countries } \\
\text { by the share of tempo- } \\
\text { rary workers in total } \\
\text { employment (\%) }\end{array}$ \\
\hline \hline 1 & 2 & 3 & 4 & 5 & 6 & \multirow{2}{*}{ Group 1 } \\
\hline The Netherlands & 40,3 & 46,8 & 6,5 & 16,1 & 8,3 & \multirow{2}{*}{ Group 2 } \\
\hline Switzerland & 31,3 & 38,5 & 7,2 & 23,0 & 10,9 & \\
\hline Austria & 19,3 & 27,6 & 8,3 & 43,0 & 0,8 & \\
\hline Germany & 20,5 & 26,8 & 6,3 & 30,7 & 2,8 & \\
\hline Belgium & 19,0 & 24,0 & 5,0 & 26,3 & & \\
\hline
\end{tabular}


Temporary and part-time employment...

\begin{tabular}{|c|c|c|c|c|c|c|}
\hline 1 & 2 & 3 & 4 & 5 & 6 & 7 \\
\hline Norway & 23,4 & 23,9 & 0,5 & 2,1 & 0,1 & \multirow{8}{*}{ Group 3} \\
\hline Great Britain & 22,7 & 23,3 & 0,6 & 2,6 & 0,6 & \\
\hline Sweden & 18,8 & 21,3 & 2,5 & 13,3 & 2,0 & \\
\hline Denmark & 16,5 & 20,7 & 4,2 & 25,5 & 0,6 & \\
\hline European Union & 14,9 & 18,5 & 3,6 & 24,2 & 2,2 & \\
\hline Iceland & 24,6 & 18,4 & $-6,2$ & $-25,2$ & 0,1 & \\
\hline Italy & 8,5 & 18,3 & 9,8 & 115,3 & 0,1 & \\
\hline Ireland & 15,0 & 18,1 & 3,1 & 20,7 & 0,2 & \\
\hline France & 15,9 & 17,8 & 1,9 & 11,9 & 0,3 & \multirow{4}{*}{ Group 4} \\
\hline Luxembourg & 11,6 & 17,5 & 5,9 & 50,9 & 0,3 & \\
\hline Spain & 7,8 & 14,2 & 6,4 & 82,1 & 3,3 & \\
\hline Finland & 10,4 & 13,6 & 3,2 & 30,8 & 0,6 & \\
\hline Malta & 7,3 & 12,3 & 5,0 & 68,5 & 1,3 & \multirow{15}{*}{ Group 5} \\
\hline Cyprus & 6,3 & 10,6 & 4,3 & 68,3 & 1,7 & \\
\hline Estonia & 6,1 & 10,5 & 4,4 & 72,1 & 0,1 & \\
\hline Slovenia & 5,2 & 9,1 & 3,9 & 75,0 & 1,4 & \\
\hline Greece & 4,1 & 9,0 & 4,9 & 119,5 & 0,1 & \\
\hline Portugal & 8,4 & 7,8 & $-0,6$ & $-7,1$ & 1,2 & \\
\hline Latvia & 8,8 & 7,1 & $-1,7$ & $-19,3$ & 0,7 & \\
\hline Lithuania & 9,5 & 6,9 & $-2,6$ & $-27,4$ & 0,2 & \\
\hline Romania & 9,4 & 6,3 & $-3,1$ & $-33,0$ & 0,6 & \\
\hline Czech & 4,2 & 6,2 & 2,0 & 47,6 & 0,1 & \\
\hline Poland & 8,9 & 6,2 & $-2,7$ & $-30,3$ & 0,0 & \\
\hline Croatia & 6,5 & 4,9 & $-1,6$ & $-24,6$ & 1,3 & \\
\hline Slovakia & 1,8 & 4,8 & 3,0 & 166,7 & 0,1 & \\
\hline Hungary & 3,4 & 4,2 & 0,8 & 23,5 & 0,6 & \\
\hline Bulgaria & 2,7 & 1,8 & $-0,9$ & $-33,3$ & 2,4 & \\
\hline
\end{tabular}

Part-time employment trends for the period of 2002-2018 in the context of European countries show that most countries see its absolute increase. The exceptions are the Baltic countries, Eastern European countries, Iceland and Portugal.

Part-time work is particularly widespread in the Netherlands, where it accounted for approximately $46.8 \%$ of total employment in 2018; same for Switzerland (38.5\%). These were followed by Austria, Germany, Belgium, the United Kingdom, Sweden and Denmark, where part-time work would account for more than one-fifth $(21 \%)$ of the employed in each case. In contrast, part-time employment was relatively rare in Bulgaria (1.8\% of the employed); same for Croatia, Hungary, Slovakia and Poland (4.2\% to $6.2 \%)$.

Let us perform a statistical analysis on Table 3 data and calculate the coefficient of variation for the share of part-time workers in European countries (Table 4). Grouping data in column 6 has shown the largest coverage of countries in group 5; these are mainly countries with low rates of part-time employment from 1 to $7 \%$.

Table 4. Variation values for 2002 and 2018 (\%)

\begin{tabular}{|l|c|c|c|}
\hline \multicolumn{1}{|c|}{ Indicators } & 2002 & 2018 & Absolute variation \\
\hline Variation range & 38,5 & 45 & $+6,5$ \\
\hline Mean value & 12,91 & 15,53 & $+2,62$ \\
\hline Standard deviation & 8,9 & 10,06 & $+1,16$ \\
\hline Coefficient of variation & 68,95 & 64,78 & $-4,17$ \\
\hline Note-Compiled by the authors based on Table 3
\end{tabular}

The range of variation has increased by 6.5 p. p. in 2018 and amounted to $45 \%$, which speaks of a large gap between the minimum and maximum values, and high fluctuations in the share of part-time workers in European countries. Also, the average value and standard deviation indicators have a positive growth trend, which increased by 2.62 p.p. and 1.16 p.p., respectively. In many countries, the proportion of part-time workers differs significantly from the average, which is confirmed by a wide range of data.

The coefficient of variation is twice the threshold level (33\%), therefore the distribution of part-time employment across Europe is heterogeneous and the calculated average is not reliable. The coefficient of 
variation value's tendency to decrease by 4.17 p.p. by the end of the period compared to its beginning, i.e. in our case in the period of 2002-2018, reflects the movement towards homogeneity and closer to a more stable state of temporary employment growth in European countries.

EU countries would regulate part-time employment differently and with different consequences for the rights and protection of workers. The Netherlands was particularly notable for its flexible reforms. The flexibility of the labor market, along with wage restrictions and public sector cuts, is seen as one of the important steps that have turned the situation in the Dutch economy from a Dutch disease into a Dutch miracle. Trade unions in the Netherlands would protect work and promote the distribution of work as a means of preventing unemployment. Early retirement and advocacy for women to stay home as full-time housewives were used to reduce the labor supply. In 1982, the "Wassenaar arrangement" was concluded between employers and trade union representatives. Its main feature was that the unions agreed to lower wage requirements in exchange for a shorter working week. This agreement was a turning point. In the Netherlands, the flexibility of the labor market was internal: firms were given more rights to use their labor force, and the need to pay overtime bonuses disappeared. This policy moved part-time employment from a lower position to the common law and allowed for shorter or longer working hours in any job. The Netherlands moved closest to the European Union's intentions for the so-called "Part-Time Work Directive" (1997). By the mid-1990s, the Netherlands was a fast-growing economy with stable employment growth and 1.8 million jobs consisting exclusively of part-time employment in 1996. The Netherlands has been called "world's first part-time economy," as almost half of its employees work part-time.

The Netherlands, Sweden and Germany legislation provides part-time workers with equal rights with full-time workers in paying per hour. Work-related benefits are applied in proportion to hours worked.

Part-time work is increasing with the growth of the women's labor market (Figure 2). On the demand side, part-time employment is used most to meet organizational or economic needs. For example, peaks in maintenance needs. Also, part-time work frees the employer from the cost of benefits and payments, which gives economic benefits and the opportunity to invest in business. On the other hand, part-time work also meets the needs of employees to the extent that they want to combine paid work with other activities, such as child care or retirement (Salladarre, Hlaimi, 2014).

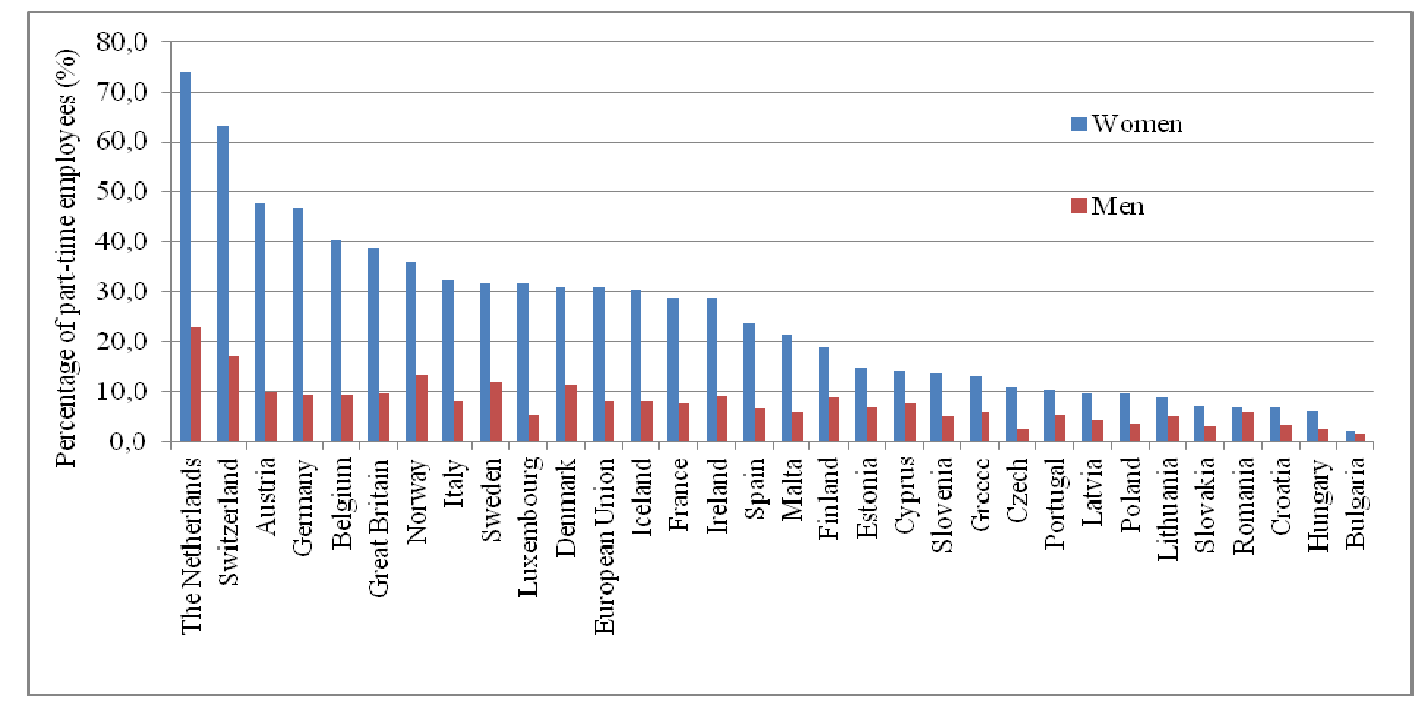

Figure 2. Gender features of part-time employment in European countries in 2018 (\%)

Note-Compiled by the authors

Figure 2 shows a notable difference in the part-time work prevalence between men and women. In the European Union, the proportion of women aged 20-64 working part-time was 30.8\%, which is much higher than the corresponding proportion for men of $8.0 \%$. About three-quarters $(73.8 \%)$ of women and just under a quarter of men (23.0\%) working in the Netherlands would work part-time in 2018. This is the highest rate among EU Member States.

Part-time work in the Netherlands is present in all profession and educational groups, while in many other countries part-time work is limited to low-skill jobs. 
We believe that part-time employment's increasing trend will progress as part-time work is more flexible than a fixed-term contract. If the law allows for it, the employer can at any time, depending on the market demand for its goods and services, transfer the employee to a partial form of work, but keep him in the staff. This gives him an advantage in the case of a favorable scenario in the transition to economic growth, when a proven employee with the necessary qualifications can be transferred to longer working hours without additional training costs.

The final ranking of countries by the sum of specific weights of temporary and part-time employment in the total employment of the population of countries is shown in Table 5.

Table 5. The share of non-standard types of employment in the total employment of the population of countries in $2018(\%)$

\begin{tabular}{|l|c|c|c|}
\hline \multicolumn{1}{|c|}{ Countries } & $\begin{array}{c}\text { Temporary } \\
\text { employment }\end{array}$ & $\begin{array}{c}\text { Part-time } \\
\text { employment }\end{array}$ & $\begin{array}{c}\text { The share of non-standard types of employment } \\
\text { in economy (\% in employment) }\end{array}$ \\
\hline The Netherlands & 17,6 & 46,8 & 64,4 \\
\hline Switzerland & 9,1 & 38,5 & 47,6 \\
\hline Spain & 26,4 & 14,2 & 40,6 \\
\hline Germany & 10,8 & 26,8 & 37,6 \\
\hline Italy & 16,8 & 18,3 & 35,1 \\
\hline Sweden & 13,8 & 21,3 & 35,1 \\
\hline Austria & 6,8 & 27,6 & 34,4 \\
\hline Belgium & 9,8 & 24,0 & 33,8 \\
\hline France & 15,5 & 17,8 & 33,3 \\
\hline EU-28 & 13,2 & 18,5 & 31,7 \\
\hline Norway & 7,4 & 23,9 & 31,3 \\
\hline Poland & 23,9 & 6,2 & 30,1 \\
\hline Denmark & 8,8 & 20,7 & 29,5 \\
\hline Portugal & 21,5 & 7,8 & 29,3 \\
\hline Finland & 14,9 & 13,6 & 28,5 \\
\hline Great Britain & 4,9 & 23,3 & 28,2 \\
\hline Luxembourg & 9,3 & 17,5 & 26,8 \\
\hline Ireland & 8,6 & 18,1 & 26,7 \\
\hline Iceland & 8,1 & 18,4 & 26,5 \\
\hline Cyprus & 13,7 & 10,6 & 24,3 \\
\hline Croatia & 19,3 & 4,9 & 24,2 \\
\hline Slovenia & 14,8 & 9,1 & 23,9 \\
\hline Greece & 11,2 & 9,0 & 20,2 \\
\hline Malta & 7,4 & 12,3 & 19,7 \\
\hline Czech & 8,2 & 6,2 & 14,4 \\
\hline Estonia & 3,0 & 10,5 & 13,5 \\
\hline Slovakia & 7,8 & 4,8 & 12,6 \\
\hline Hungary & 7,1 & 4,2 & 11,3 \\
\hline Latvia & 2,6 & 7,1 & 9,7 \\
\hline Lithuania & 1,4 & 6,9 & 8,3 \\
\hline Romania & 1,1 & 6,3 & 7,4 \\
\hline Bulgaria & 3,9 & 1,8 & 5,7 \\
\hline Note: Compiled by the authors based on Eurostat, 2020$)$ & \\
\hline & & & \\
\hline
\end{tabular}

On average, the share of non-standard contracts in the EU is $31.7 \%$, which means that almost every third European citizen works either temporarily or part-time.

All developed European countries have a high proportion of non-standard employees in their economies, and the share of part-time employment is significantly higher than temporary one. Variation between countries is quite significant: $64.4 \%$ for the Netherlands and $5.7 \%$ for Bulgaria.

As Table 5 shows, the top three in this rating are the countries with the highest rates of non-standard employment: the Netherlands (64.4\%), Switzerland (47.6\%), and Spain (40.6\%).

In general, there is a growing trend in the number of part-time work contracts in most European countries, which indicates a high prevalence of this employment form. 
Companies opt for part-time work to retain older, skilled workers who might otherwise retire, and to attract and retain workers for specific schedules or complex jobs, especially in developed industrial countries. Some social groups, such as women with children, students, and older workers, are offered an opportunity to get paid work.

Temporary employment also tends to increase, especially in countries where agriculture is one of the areas of specialization. Tendency to increase non-standard employment forms is gaining momentum in Europe.

\section{Discussion}

In a rapidly developing post-industrial society, new systems of labor organization are emerging and transformational processes are taking place in employment. Many scientists try to determine features and factors of development of these processes. Our approach to the classification of factors supports the point of view expressed by Zenkova O.A.: "we require systematic updating of data on the factors of the growth of non-standard employment forms." In this regard, this paper highlights subjective and objective factors, including economic, social and legal components (Bak-Grabowska, Jagoda, 2016).

We disagree with Bobkov, V.N. (2018) in saying that "non-standard employment is increasingly acquiring features of unstable employment manifesting itself as a forced one." In many countries, non-standard employment is rising to the level of typical since the flexible labor market provides certain freedom to the subjects of labor relations. For example, employers are guaranteed interchangeability of employees, reduced costs, and a flexible wage system. For employees, a flexible labor market provides opportunities for additional income, to combine professions, to optimize the structure of their life activities, etc. That is, in our research, we consider non-standard employment rather in a positive perspective.

Our results confirm Monusova's conclusions that the distribution of non-standard employment is heterogeneous in the European area. The analysis of the main trends reflects sharp disparities in growth and coverage of flexible employment forms in Europe. We have identified countries that have been leaders for several periods, and countries where the non-standard work is almost non-existent.

For example, we are attracted to the opinion expressed by (Huws, Spencer, Syrdal (2018) that "the lack of a flexible labor market is recognized as a factor contributing to economic stagnation and unemployment." Growth trends in temporary and part-time employment, revealed as a result of the analysis, show the trend of economic growth and employment in European countries.

We also agree with the fact that the growth of non-standard employment was significantly influenced by demographic shifts in the structure of the labor force, which was manifested in the mass entry into the labor market of women, pensioners and young people (Salladarre, Hlaimi, 2014).

\section{Conclusion}

The paper reviews data on prevalence and trends of such forms of non-standard employment as temporary and part-time employment. The analysis has shown the growth trends for these employment forms in the labor market, which largely reflects the evolution of labor markets in the new techno-economic paradigm accompanied by legal regulation and economic crises.

Both part-time and temporary employment types have been growing in many countries since 2000. In Europe, almost one in five employees work part-time. In the Netherlands, almost one in two employees, and in Switzerland, one in three has a part-time contract, most of whom are women. Although the reasons for working part-time vary, about a third of part-time European citizens are on this type of contract because they failed to find a full-time job.

The paper examines non-standard forms of employment and highlights the factors of their distribution. As shown by statistical analysis, trends temporary and part-time employment vary greatly between countries. This indicates the heterogeneity of European countries on this topic. Indeed, a number of countries enjoy a significant increase and a large coverage scale. And yet there are countries where the applicability of fixedterm and incomplete contracts is quite low, and even if it sees an increase, it is still a very slight one. High values of the coefficient of variation confirm the heterogeneity of European countries in this indicator.

With the general trend of increasing the share of temporary and part-time employment on average in the $\mathrm{EU}$, countries have their own features. In those countries where agriculture and processing of its products is an industry of specialization and occupies a significant share in the structure of GDP, temporary employment is progressing. This includes Spain, Poland, Greece, Croatia, Slovenia, and Cyprus. In countries with competitive industries and banks (Germany, the Netherlands, Switzerland, Belgium), part-time employment 
dominates, which allows to maneuver in a changing environment and retain workers depending on the stage of the economic cycle.

The prevalence of non-standard employment also depends on the strictness of the legal framework in the context of standard employment protection and the benefits that non-standard contracts provide in comparison with it. If the rights of temporary and part-time workers are protected equally, these contracts are applied less frequently, but unfortunately, unemployment and illegal employment tend to be higher.

\section{References}

Avlijas, S. (2019). The dynamism of the new economy: Non-standard employment and access to social security in EU28. LEQS Paper, 141, 1-78. Retrieved from http://www.lse.ac.uk/european-institute/research/leqs-discussion-paperseries

Bak-Grabowska, D. \& Jagoda, A. (2016). Non-standard forms of employment and working time flexibility — the categories of co-occurrence? Journal of International Studies, Vol. 9, 1, 229-239. Doi: 10.14254/2071-8330.2016/9$1 / 17$

Employment Statistics. Eurostat. ec.europa.eu. Retrieved from http://ec.europa.eu/eurostat/statisticsexplained/index.php/ Employment_statistics (accessed 25.02.2020).

Huws, U., Spencer, N.H. \& Syrdal, D.S. (2018). Online, on call: the spread of digitally organized just-in-time working and its implications for standard employment models. New Technology, Work and Employment Journal, 33(2), 113129. ISSN 1468-005X

Imdorf, C., Helbling, L.A. \& Inui, A. (2017). Transition systems and non-standart employment in early career: comparing Japan and Switzerland. Journal of Education and Work, 30(5), 486-500, DOI: 10.1080/13639080.2016.1243234

Kalleberg, A. (2000). Nonstandart Employment Relations: Part-Time, Temporary and Contract Work. Annual Review of Sociology, Vol. 26, 341-365.

Non-standard employment around the world: Understanding challenges, shaping prospects [Text] / International Labour Organization; International Labour Office. Geneva: ILO (2016).

OECD stat. stats.oecd.org. Retrieved from http://stats.oecd.org (accessed 12.02.20)

Salladarre, F. \& Hlaimi, S. (2014). Women and part-time work in Europe. International Labour Review Journal, Vol. 153, 2, 293-310.

Schoukens, P., Barrio, A. \& Montebovi, S. (2018). The EU social pillar: An answer to the challenge of the social protection of platform workers? European Journal of Social Security, 20 (3), 219-241. DOI: $10.1177 / 1388262718798393$

Bobkov, V.N. (2018). Kharakteristiki neustoichivosti standartnoi i nestandartnoi zaniatosti v sovremennoi Rossii [Characteristics of instability of standard and non-standard employment in contemporary Russia]. Mir novoi ekonomiki Word of the new economy Journal, 12(3), 128-139 [in Russian].

Gimpel'son, V. \& Kapelyushnikov, R. (2006). Nestandartnaia zaniatost [Non-standart employment]. Moscow: HUVShE [in Russian].

Monusova, G.A. (2018). Vremennaia zaniatost na evropeiskom rynke truda [Temporary employment in Europe]. Mirovaia ekonomika i mezhdunarodnye otnosheniia - World Economy and International Relations, 9, 36-47. https://doi.org/10.20542/0131-2227-2018-62-9-36-47 [in Russian].

Musayev, B.A. (2017). Nestandartnaia zaniatost kak forma realizatsii uslovii novoho ekonomicheskoho uklada [Precarious employment as a form of realization of new economic order]. Naukovedenie - Science, 2, 1-7. Retrieved from http://naukovedenie.ru/PDF/59EVN217.pdf [in Russian].

Orynbassarova, Y., Serikova, G., Pritvorova, T., Legostayeva, A., Kuttybaeva, N. \& Komekbayeva, L. (2019). Parttime and temporary employment in modern conditions of the Republic of Kazakhstan: scope and priorities of social protection. Entrepreneurship and Sustainability Issues. https://doi.org/10.9770/jesi.2019.7.1(52)

Pritvorova, T.P. \& Tasbulatova B.K., (2020). Implementation of a compatibility assessment of the activation system to the employee motivational profile in company human resources management. Vestnik Karahandinskoho universiteta. Seriia Yekonomika - Bulletin of the Karaganda University. Economy Series, 1(97), 88-100 [in Russian].

Shelomentseva, V.P., Bespalyy, S.V., Beisembayeva, G.M. \& Soltangazinov, A.R. (2019). Self-employment of economically active population in the region. Vestnik Karahandinskoho universiteta. Seriia Yekonomika - Bulletin of the Karaganda University. Economy Series, 2(94), 80-87 [in Russian].

Taubayev, A.A., Legostayeva, A.A., Serikova, G.S. \& Orynbassarova, Y.D. (2019). Non-standard employment in Kazakhstan: scales, tendencies and social protection measures. Vestnik Karahandinskoho universiteta. Seriia Yekonomika - Bulletin of the Karaganda University. Economy Series, 1(93), 31-40 [in Russian].

Zenkova, O.A. (2017). O nekotorykh faktorakh rasprostraneniia nestandartnykh form zaniatosti [About some factors of non-standard forms of employment spread]. Vestnik Voronezhskoho universiteta. Seriia Yekonomika - Bulletin of the Voronezh University. Economy Series, 3, 85-89. Retrieved from http://www.vestnik.vsu.ru/pdf/econ/2017 /03/2017-03-13.pdf [in Russian]. 


\section{Т.П. Притворова, С.Г. Симонов, А.К. Атабаева \\ Еуропалық еңбек нарығындағы уақытша және толық емес жұмыспен қамту: факторлар, тенденциялар, ерекшеліктер}

\section{Aңдатnа:}

Maқ̧cambl: Еуропада постиндустриалды экономика жағдайында елдің сипаттамалары мен даму тенденцияларын анықтау үшін уақытша және ішінара жұмыспен қамтудың пайда болу факторларын зерттеу болып табылады.

Әдісі: Зерттеу мақсатында статистикалық топтау, динамика, құрылым және өзгеру әдістері қолданылды. Еуропа елдеріндегі уақытша және толық емес жұмыспен қамтудың өзгеруін статистикалық талдау өзгеру коэффициентіне негізделген. Сондай-ақ біз Eurostat және Еуропалық әлеуметтік шолу (ESS) деректерін пайдаландық.

Kopытынды: Стандартты емес еңбек нысандарының пайда болуына ықпал ететін ерекшеліктері, объективті және субъективті факторлар анықталды. Біз еуропалық елдердің тұрғындарының зерттелген стандартты емес жұмыс түрлері бойынша уақытша және толық емес біртектілігін бағаладық. Алынған нәтижелер негізінде Еуропада уақытша және толық емес жұмыспен қамтылудың таралуы анықталды. Халықты жұмыспен қамтудың стандартты емес түрлерінің үлесі бойынша елдердің рейтингісі негізінде біз аталған рейтингтің көшбасшылары мен аутсайдерлерін анықтадық.

Тұжырымдама: Статистикалық талдау уақытша және толық емес жұмыспен қамтылғандардың өсуін көрсетті; бұл Еуропа елдеріндегі еңбек нарығының даму тенденцияларының бірін көрсетеді. Вариация шамасының жоғары коэффициенті Еуропа елдерінің уақытша және толық емес жұмыспен қамтылу үлесінің біртектілігін көрсетеді. Шынында да, бірқатар елдер айтарлықтай өсуге және қамту ауқымына ие. Мерзімді және аяқталмаған келісімшарттардың қолданылу мүмкіндігі өте төмен елдер бар, ал егер ол өссе де, бұл өте аз. Гетерогенділіктің негізгі себептері қазіргі экономикалық жағдайға және белгілі бір елдегі өндірістің даму деңгейіне байланысты. Сондай-ақ қолданыстағы нормативтік құқықтық актілер мен қызметкерлердің құқықтарын қорғау жөніндегі шараларда айырмашылықтар бар.

Kiлm сөздер: уақытша жұмыспен қамту, толық емес жұмыс уақыты, факторлар, үрдістер, елдердің біртектілігі, еуропалық еңбек нарығы.

\section{Т.П. Притворова, С.Г. Симонов, А.К. Атабаева \\ Временная и частичная занятость на европейском рынке труда: факторы, тенденции, особенности}

\section{Аннотация:}

Цель: Исследовать факторы возникновения временной и неполной занятости в Европе для определения страновых особенностей и тенденций их развития в постиндустриальной экономике.

Memodbl: При проведении исследования были использованы методы статистической группировки, анализа динамики, структуры и вариации. Статистический анализ вариации временной и частичной занятости в европейских странах проведен на основе коэффициента вариации. Информационной базой являются данные Евростата и Европейского социального обследования (ESS).

Pезультаты: Выявлены особенности, а также объективные и субъективные факторы, способствующие возникновению нестандартных форм занятости. Оценена однородность совокупности европейских стран по исследуемым видам нестандартной занятости - временной и неполной. По полученным результатам определена степень распространенности временной и частичной занятости в Европе. На основе рейтинга стран по удельному весу нестандартных видов занятости в общем объеме занятости населения определены лидеры и аутсайдеры этого рейтинга.

Bblвoдbl: Статистический анализ показал динамику роста временной и неполной занятости, что отражает одно из направлений эволюции рынков труда европейских стран. Высокие показатели коэффициента вариации говорят о неоднородности стран Европы по доле временно и частично занятых. В ряде стран, действительно, фиксируются их существенный рост и масштабность охвата, однако есть страны, где применимость срочных и неполных контрактов достаточно низка, а если и увеличивается, то незначительно. Главные причины неоднородности зависят от сложившейся экономической ситуации и уровня развития производства в той или иной стране. А также кроются в различиях применяемых нормативно-правовых актов и мер по защите прав работников.

Ключевые слова: временная занятость, неполная занятость, факторы, тенденции, неоднородность стран, европейский рынок труда.

\section{References}

Avlijas S. The dynamism of the new economy: Non-standard employment and access to social security in EU-28 / S. Avlijas // LEQS Paper. — 2019. — № 141. — P. 1-78. 
Bak-Grabowska D. Non-standard forms of employment and working time flexibility - the categories of cooccurrence? / D. Bak-Grabowska, A. Jagoda // Journal of International Studies. — 2016. — Vol. 9, № 1. — P. 229239.

Huws U. Online, on call: the spread of digitally organized just-in-time working and its implications for standard employment models / U. Huws, N.H. Spencer, D.S. Syrdal // New Technology, Work and Employment Journal. 2018. - № 33(2). — P. 113-129.

Imdorf C. Transition systems and non-standart employment in early career: comparing Japan and Switzerland / C. Imdorf, L.A. Helbling, A. Inui // Journal of Education and Work. — 2017. — No. 30(5). — P. 486-500.

Eurostat Employment statistics, 2020. (www.ec.europa.eu).

Kalleberg A. Nonstandart Employment Relations: Part-Time, Temporary and Contract Work / A. Kalleberg // Annual Review of Sociology. — 2000. — Vol. 26. - P. 341-365.

Non-standard employment around the world: Understanding challenges, shaping prospects. — Geneva: ILO, 2016. — P. 375.

OECD database, 2020. (http://stats.oecd.org).

Orynbassarova Y. Part-time and temporary employment in modern conditions of the Republic of Kazakhstan: scope and priorities of social protection / Y. Orynbassarova, G. Serikova, T. Pritvorova, A. Legostayeva, N. Kuttybaeva, L. Komekbayeva // Entrepreneurship and Sustainability Issues. — 2019. — № . 7(1). — P. 731-746.

Pritvorova, T.P. Implementation of a compatibility assessment of the activation system to the employee motivational profile in company human resources management / T.P. Pritvorova, B.K. Tasbulatova // Vestnik Karahgandinskogo Universiteta. — 2020. — № 1(97). - P. 88-100.

Salladarre F. Women and part-time work in Europe / F. Salladarre, S. Hlaimi // International Labour Review Journal. 2014. - Vol. 153, № 2. - P. 293-310.

Schoukens P. The EU social pillar: An answer to the challenge of the social protection of platform workers? / P. Schoukens, A. Barrio, S. Montebovi // European Journal of Social Security. — 2018. — № 20 (3). — P. 219241.

Shelomentseva V.P. Self-employment of economically active population in the region / V.P. Shelomentseva, S.V. Bespalyy, G.M. Beisembayeva, A.R. Soltangazinov // Vestnik Karagandinskogo Universiteta. — 2019. — № 2(94). - P. 80-87.

Taubayev A.A. Non-standard employment in Kazakhstan: scales, tendencies and social protection measures / A.A. Legostayeva, G.S. Serikova, Y.D. Orynbassarova // Vestnik Karahandinskoho universiteta. — 2019. — № 1(93). - P. 31-40.

Бобков В.Н. Характеристики неустойчивости стандартной и нестандартной занятости в современной России / В.Н. Бобков // Мир новой экономики. - 2018. - № 12(3). — С. 128-139.

Гимпельсон В. Нестандартная занятость [Текст] / В. Гимпельсон, Р. Капелюшников. — М.: ГУ ВШЭ, 2006. $398 \mathrm{c}$.

Зенкова О.А. О некоторых факторах распространения нестандартных форм занятости / О.А. Зенкова // Вестн. Воронеж. ун-та. — 2017. — № 3. - С. 85-89.

Монусова Г.А. Временная занятость на европейском рынке труда / Г.А. Монусова // Мировая экономика и международные отношения. - 2018. - № 9. - С. 36-47.

Мусаев Б.А. Нестандартная занятость как форма реализации условий нового экономического уклада / Б.А. Мусаев // Науковедение. — 2017. — № 2. — С. 1-7. 